\title{
Occurrence of Clostridium difficile in seasoned hamburgers and seven processing plants in Iran
}

\author{
Zahra Esfandiari ${ }^{1}$, Scott Weese ${ }^{2}$, Hamid Ezzatpanah ${ }^{1}$, Mohammad Jalali $^{2^{*}}$ and Mohammad Chamani ${ }^{3}$
}

\begin{abstract}
Background: The recent increment of the incidence of Community Associated Clostridium difficile Infection (CA)-CDI has led to speculation that this disease is associated to foodborne transmission. Therefore it is critical to establish the community sources of CDI in order to implement the appropriate interventions. The present study was conducted to evaluate the prevalence of $C$. difficile in seasoned hamburger and examine the sources of C. difficile dispersal in hamburger processing plants. A total of 211 samples including hamburger ingredients, the final product, processing equipment and food contact surfaces were collected from seven hamburger processing plants to evaluate the routes of dispersal of $C$. difficile. The samples were assessed for the occurrence of $C$. difficile using culture and polymerase chain reaction (PCR) methods. All isolates were screened for the existence of toxin $A$, $B$ and binary toxin genes. In addition, isolates were subjected to PCR ribotyping.

Results: Overall, 9/211 (4.2\%) samples were positive. Toxigenic C. difficile were detected from 2/7 (28.5\%) hamburger processing plants, in (3/54) $5.6 \%$ of beef meat samples, (2/56) 3.5\% of swabs taken from the environment and (4/56) 7.1\% of hamburger samples after both molding and freezing. C. difficile was not found in 45 non-meat ingredients including 14 defrosted onions, 14 textured soy proteins and 17 seasonings. All isolates contained $t c d B$ gene while 7 strains were positive for $t c d A$ and two remaining strains were negative for $t c d A$. None of the isolates harbored binary toxin gene (cdtB). PCR ribotyping of 9 isolates categorized into four ribotypes (IR21, IR 22, IR 23 and IR24). Ribotype IR 22 was the most common type 6/9 (66.6\%) found. This genotype was isolated from raw meat, environmental samples and hamburger after both forming and freezing in one processing plant, suggesting raw beef meat as a possible major source of contamination.
\end{abstract}

Conclusions: Hyper-virulent strains of ribotype were not found in this study however, occurrence of other toxicgenic strains indicate the public health significance of contamination of this product.

Keywords: Clostridium difficile, Meat, Processing plants, Ribotyping

\section{Background}

Clostridium difficile is an anaerobic Gram-positive endospore forming bacterium that is considered to be the most significant cause of nosocomial infection acquired in humans (CDI) [1]. To date, the most significant epidemic strain of $C$. difficile encountered in healthcare facilities within North America and Europe has been a strain classified by restriction enzyme analysis are BI, pulsed field gel electrophoresis (PFGE) as NAP1 and PCR ribotyping as ribotype 027 (B1/NAP-1/027) [2]. This strain

\footnotetext{
*Correspondence: mjalali@uoguelph.ca

${ }^{2}$ Department of Pathobiology and Centre for Public Health and Zoonoses, Ontario Veterinary College, University of Guelph, Guelph, Ont N1G2W1, Canada

Full list of author information is available at the end of the article
}

is widely disseminated internationally and as a common cause of both endemic and epidemic CDI. In addition, recent increases in community associated (CA)-CDI in patients with no recent contact with clinical environments has led to speculation of other potential sources of exposure. The potential that CDI could be a foodborne disease has been raised based on variable but often high rates of C. difficile colonization of food animals and identification of $C$. difficile in retail meat products [3-9]. Additionally, ribotype 078 , a strain commonly associated with CA-CDI, is a predominant strain in food animals and food heightening concerns of a possible food origin $[4,10]$.

Data regarding the contamination of food of animal origin are mostly reported from Europe and North America. These studies have focused mostly on the prevalence of 
C. difficile at the farm or retail level, and only a few surveys have been performed at meat processing plants [6,7,11-13]. Rodriguez-Palacios et al (2007) reported the presence of $C$. difficile up to $20 \%$ in unseasoned hamburgers in Canada [3]. Further studies indicated that $C$. difficile spores are relatively unaffected by processing such as freezing, refrigeration and cooking ([14-16]. Furthermore, the epidemiology and prevalence of $C$. difficile in food in Iran are limited, despite the importance of CDI and a previous study that found ribotype 078 to be a leading cause of CDI in people at one hospital in Isfahan, Iran [17]. The rate of CA-CDI reported to be $24 \%$ in Iran, with no data available on sources of infection [17].

Therefore, the objective of the present study was to determine the prevalence of $C$. difficile in seasoned hamburger and examine the sources of $C$. difficile dispersal in hamburger processing plants in the same location in Iran.

\section{Methods}

\section{Sampling design}

This study was conducted in Isfahan, central part of Iran (subtropical zone; mean long time rainfall, $120 \mathrm{~mm}$; mean long time temperature, $33^{\circ} \mathrm{C}$ and $17.6^{\circ} \mathrm{C}$ in summer and autumn; altitude, $1,555 \mathrm{~m}$; longitude, $51^{\circ} 30^{\prime} \mathrm{E}$; and latitude, $\left.32^{\circ} 31^{\prime} \mathrm{N}\right)$. Samples were taken from seven (coded A to G) available hamburger processing plants that supply products nationwide from July to December 2012. Samples collected during four visits (two visits in summer and two visits in autumn). Three of seven processing plants (coded A, B and G) were Hazard Analysis Critical Control Points (HACCP) certified. However, all processing plants were ranked in terms of Quality Assurance Managements (QA) and implementation of Good Manufacturing Practice (GMP) by the Ministry of Health (Category I, II and II). The hamburger patties consisted of $35 \%$ texturized soy protein, $30 \%$ beef meat, $16 \%$ onion, $9 \%$ frying oil, $8 \%$ wheat flour, $1.7 \%$ salt and $0.3 \%$ irradiated seasonings. The ground product was molded, sandwiched between two waxed paper sheets, packaged and frozen at $-18^{\circ} \mathrm{C}$ for $24 \mathrm{~h}$ (Figure 1). Samples were collected based on their production day per week (one or two day production per week). At the hamburger processing plants, the ingredients had a different expiry dates and the irradiated seasonings, texturized soy protein and frozen onion, kept for longer time (for more than a few months). Therefore these products sampled less frequently than the beef meat (normally supplied on weekly bases) as a main ingredient of hamburger.

A total of 211 samples were obtained including: beef meat $(\mathrm{n}=54)$, textured soy protein $(\mathrm{n}=14)$ irradiated seasoning $(\mathrm{n}=17)$, defrosted onion $(\mathrm{n}=14)$, hamburger

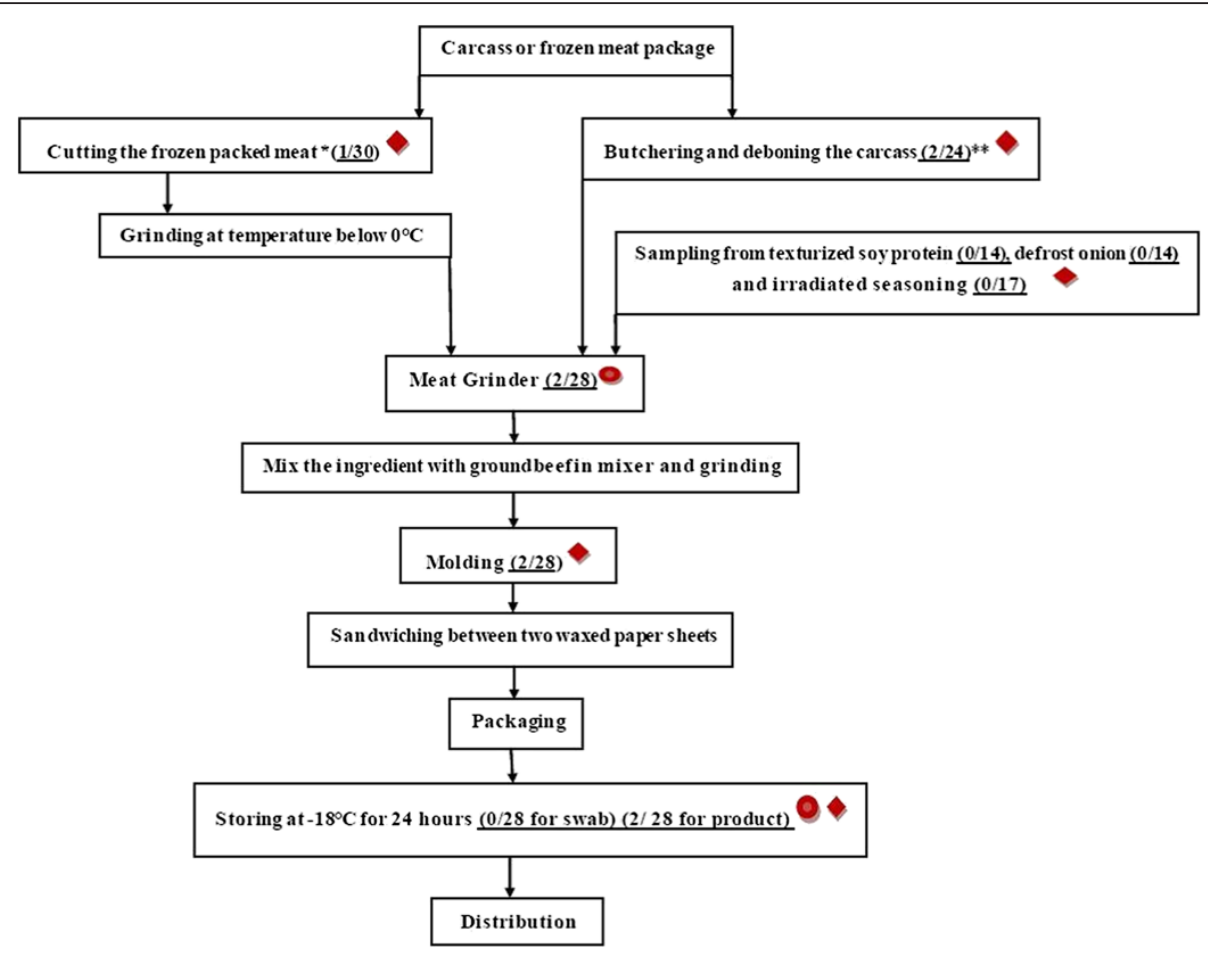

Figure 1 Flow diagram for the production of hamburgers with sampling points (red diamonds for ingredient/final product and red circles for swab samples). *Packed boneless meat imported from Brazil. ${ }^{*}$ Carcass meat provided from slaughterhouses in Iran (Number of positive samples for $C$. difficile in total sample is mentioned in parenthesis in related box). 
patties after molding $(\mathrm{n}=28)$ and hamburger patties after freezing $(\mathrm{n}=28)$. Approximately 5-10 gram of each sample were collected aseptically in sterile bottles and transported in an insulated cold box to the laboratory. In addition, 56 environmental samples were taken from meat grinder and the freezer chamber wall. Cotton swabs moistened with sterile $0.85 \% \mathrm{NaCl}$ were used to collect samples from approximately $20 \mathrm{~cm}^{2}$ areas during working hours. All samples were analyzed on the day of sampling at the Infectious Diseases and Tropical Medicine Research Centre, Isfahan University of Medical Sciences, Isfahan, Iran.

\section{Isolation of C. difficile}

For culture analysis, a method of Rodriguez-Palacios et al. [3] was used. Briefly, $5 \mathrm{~g}$ of sample or swabs was added to $25 \mathrm{ml}$ of selective enrichment $C$. difficile broth (1 liter containing $40 \mathrm{~g}$ proteose peptone, $5 \mathrm{~g}$ disodium hydrogen phosphate, $1 \mathrm{~g}$ potassium dihydrogen phosphate, $0.1 \mathrm{~g}$ magnesium sulfate, $2 \mathrm{~g}$ sodium chloride, $6 \mathrm{~g}$ fructose and $1 \mathrm{~g}$ sodium taurocholate supplemented with $500 \mathrm{mg}$ cysteine hydrochloride, $12 \mathrm{mg}$ norfloxacin and $32 \mathrm{mg}$ moxalactam) in $50 \mathrm{ml}$ falcon tubes and incubated for five to seven days at $37^{\circ} \mathrm{C}$. For each sample, an alcohol shock to kill the vegetative cells was performed by adding a volume of $2 \mathrm{ml}$ of enriched broth to an equal volume of absolute ethanol in a centrifuge tube, gently vortexed and kept at room temperature for $2 \mathrm{~h}$. The samples were centrifuged at $10000 \times \mathrm{g}$ for $10 \mathrm{~min}$, after which the supernatant was removed. The pellet was streaked onto Clostridium difficile Moxalactam Norfloxacin agar medium (CDMN agar) with 7\% sheep blood and anaerobically incubated for $48 \mathrm{~h}$ at $37^{\circ} \mathrm{C}$ using an Anoxomat system (MART Microbiology B.V., Drachten, Netherlands). Isolates were presumptively identified as C. difficile by morphology, cresol/horse odor and L-proline $\beta$-naphthylamide disk (Prodisk, Hardy Diagnostics, Santa Maria, CA, USA). Culture and molecular assay were performed in a separate laboratory and negative controls were used in the entire process.

\section{Molecular characterization of isolates}

Suspected colonies were sub-cultured onto blood agar plates and incubated anaerobically at $37^{\circ} \mathrm{C} / 24 \mathrm{~h}$. DNA extraction was performed by transferring 3-5 colonies into $100 \mu \mathrm{l}$ of sterile distilled water, heating at $95^{\circ} \mathrm{C}$ for 3 min and then centrifuged at $7500 \times \mathrm{g}$ for $15 \mathrm{~min}$. The supernatant was used as a DNA-template PCR detection of genes encoding triose phosphate isomerase (tpi), toxin $\mathrm{A}$ and $\mathrm{B}$ ( $t c d A$ and $t c d B$, respectively) and binary toxin $(c d t B)$ as described by Lemee et al. [18]; Stubbs et al. [19]. Isolates were also subjected to PCR-ribotyping as described by Bidet et al. [20]. Interpretation of ribotyping results was performed by visual identification. Ribotype patterns were designated (i.e. IR22) by internal nomenclature. A reference strain of ribotype 027 was available for comparison.

\section{Results and discussion}

C. difficile was isolated from 9/211 samples (4.2\%; 95\% CI $[1,7]$ ) from $2 / 7$ (29\%) processing plants (Table 1). These two processing plants $(\mathrm{C}$ and $\mathrm{D})$ did not hold HACCP certification and were ranked in lowest level (category III) in terms of QAM and GMP. This is unsurprising because $C$. difficile contamination would be from carcass contamination by feces or intestinal contents, something that HACCP practices are designed to minimize. Similarly, lower rates of contamination of $C$. difficile in slaughterhouses have been reported when HACCP principles were implemented [11].

Raw beef meat was the only ingredient found to be contaminated with C. difficile in 3/54 (5.6\%; 95\% CI [1,15]).

Detection of $C$. difficile in raw beef was unsurprising and demonstrates the potential of meat as a source of $C$. difficile dispersal, something that is logical given its

Table 1 Occurrence of $C$. difficile in hamburger ingredients, hamburger and environmental samples within the hamburger processing plants

\begin{tabular}{|c|c|c|c|c|c|c|c|c|}
\hline \multicolumn{9}{|c|}{ \# of C. difficile positive (\%)/\# of samples } \\
\hline $\begin{array}{l}\text { Processing } \\
\text { plant }\end{array}$ & Raw meat & $\begin{array}{l}\text { Textured } \\
\text { soy protein }\end{array}$ & Seasoning & Onion & Swab & $\begin{array}{l}\text { Hamburger } \\
\text { after molding }\end{array}$ & $\begin{array}{l}\text { Hamburger } \\
\text { after freezing }\end{array}$ & Total \\
\hline A & $0 / 8(0)$ & $0 / 2(0)$ & $0 / 3(0)$ & $0 / 2(0)$ & $0 / 8(0)$ & $0 / 4(0)$ & $0 / 4(0)$ & $0 / 31(0)$ \\
\hline B & $0 / 6(0)$ & $0 / 2(0)$ & $0 / 3(0)$ & $0 / 2(0)$ & $0 / 8(0)$ & $0 / 4(0)$ & $0 / 4(0)$ & $0 / 29(0)$ \\
\hline C & $1 / 8(12.5 \%)$ & $0 / 2(0)$ & $0 / 1(0)$ & $0 / 2(0)$ & $0 / 8(0)$ & $0 / 4(0)$ & $0 / 4(0)$ & $1 / 29(3.4)$ \\
\hline D & $2 / 8(25 \%)$ & $0 / 2(0)$ & $0 / 4(0)$ & $0 / 2(0)$ & $2 / 8(25 \%)$ & $2 / 4(50)$ & $2 / 4(50)$ & $8 / 32(25)$ \\
\hline$E$ & $0 / 8(0)$ & $0 / 2(0)$ & $0 / 2(0)$ & $0 / 2(0)$ & $0 / 8(0)$ & $0 / 4(0)$ & $0 / 4(0)$ & $0 / 30(0)$ \\
\hline $\mathrm{F}$ & $0 / 8(0)$ & $0 / 2(0)$ & 0/2 (0) & $0 / 2(0)$ & 0/8 (0) & 0/4 (0) & $0 / 4(0)$ & 0/30 (0) \\
\hline G & 0/8 (0) & $0 / 2(0)$ & $0 / 2(0)$ & $0 / 2(0)$ & 0/8 (0) & 0/4 (0) & $0 / 4(0)$ & $0 / 30(0)$ \\
\hline Total & $3 / 54(5.6)$ & $0 / 14(0)$ & 0/17 (0) & $0 / 14(0)$ & $2 / 56$ & $2 / 28(7.1)$ & $2 / 28(7.1)$ & $9 / 211(4.2)$ \\
\hline
\end{tabular}


presence in food animals. However, $C$. difficile has been found in vegetables and other food items like fish, shellfish, edible bivalve molluscs, egg, ready to eat food (RTF) and salads [4,21-26], so while $C$. difficile is likely always of human or animal origin, it is important not to ignore the various potential sources that might have been contaminated by human or animal sources (e.g. manure contamination of water, indirect contamination by hands). If the main source of $C$. difficile contamination of hamburger is raw beef and this bacterium is endemic in the cattle population, it is likely that this organism can be introduced continuously.

The relatively low prevalence of $C$. difficile reported in the present study (5.6\%) is in the range of recently published studies from numerous countries reporting the isolation of $C$. difficile from raw beef spanning 1.65 to $42.4 \%$ of samples collected at retail level $[4,5,9,27,28]$. Previous Iranian data are limited, with a report of contamination of $1.65 \%$ (2/121 samples) raw beef samples (9) and 2.8\% (1/35) beef samples in meat packaging plants [29]. In contrast, this organism was not isolated from any of 145 raw chopped beef samples in the Netherlands [30].

Three different ribotypes were identified in raw beef (Table 2), with one accounting for 6/9 (67\%) isolates. This strain was only found at one plant, but it was identified at two different timepoints. It is interesting to note that 1 out of $3 C$. difficile strains was recovered from meat imported from Brazil. This strain had a distinct ribotype IR 21 pattern and was the only isolate obtained from processing plant $C$. The other contaminated beef samples originated from processing plant $\mathrm{D}$. In both samples the meat was supplied from the same Iranian slaughterhouse but with different slaughtering dates. The commonness of one strain is not surprising if one (or a small number) of strains predominate in the Iranian cattle population, as is the case with ribotype 078 in many western countries. There is inadequate information about the $C$. difficile population structure in Iranian cattle to put these results into context. Another consideration would be cross contamination within the facility, resulting in numerous positive samples from one source. Laboratory contamination cannot be dismissed, but contamination of multiple samples from just one facility when samples from other facilities were being processed in parallel would be unlikely.

C. difficile was not found in any of the 45 non-meat ingredients of hamburger (14 textured soy proteins, 17 seasoning and 14 defrosted onions). Various potential explanations can be hypothesized. One is that the raw ingredients for these materials may be less likely to be contaminated. Another is that processing might have eliminated any $C$. difficile contamination, such as the heat generated during extrusion of textured soy protein [31].

The seasoning samples collected in this study were a mixture of black pepper, cinnamon, sumac and cumin were free of $C$. difficile. Seasonings could be contaminated with spores of Clostridium species because of the lack of proper sanitary conditions during collection or as a consequence of open air drying procedures [32]. However, in the processing plants selected in this study, the seasonings were supplied to the meat processing plants after being sterilized by irradiation in $2 \mathrm{KGy}$. A dose limit of irradiation for decontamination of microbial spores is in the range of 1-4 KGy [33], so the levels used here could have inactivated any $C$. difficile spores that might have been present.

Failure to isolate $C$. difficile from onions was not particularly surprising given the small sample size, but this bacterium has been isolated from onions in UK [34]. Similarly $C$. difficile was not found in a small number of onions in a Canadian study [22].

C. difficile spores are environmentally tolerant and resistant to many disinfectants, so it is not surprising to have found contamination in 2 out of 56 of environmental sites $(3.5 \%$; $95 \%$ CI $[0,12])$. The two strains that were found isolated from one processing plant (D) during two visits approximately 6 months apart, although it is unclear

Table 2 Molecular characterization C. difficile strains isolated from hamburger and its ingredients in processing plants

\begin{tabular}{|c|c|c|c|c|}
\hline Source of isolation & $\begin{array}{c}\text { Hamburger } \\
\text { processing plant }\end{array}$ & Toxin gene profile & Ribotype & Sampling date \\
\hline Raw meat & $C$ & $t c A^{-} t c d B^{+} c d t B^{-}$ & IR21 & $17^{\text {th }}$ November \\
\hline Raw meat & D & $t c d A^{+} t c d B^{+} c d t B^{-}$ & IR22 & $4^{\text {th }}$ September \\
\hline Swab from grinder & D & $t c d A^{+} t c d B^{+} c d t B^{-}$ & IR22 & $4^{\text {th }}$ September \\
\hline Hamburger after molding & $D$ & $t c d A^{+} t c d B^{+} c d t B^{-}$ & IR22 & $4^{\text {th }}$ September \\
\hline Hamburger after freezing & $\mathrm{D}$ & $t c d A^{+} t c d B^{+} c d t B^{-}$ & IR22 & $4^{\text {th }}$ September \\
\hline Raw meat & D & $t c d A^{+} t c d B^{+} c d t B^{-}$ & IR23 & $17^{\text {th }}$ October \\
\hline Swab from grinder & $\mathrm{D}$ & $t c A^{-} t c d B^{+} c d t B^{-}$ & IR24 & $17^{\text {th }}$ October \\
\hline Hamburger after molding & $\mathrm{D}$ & $t c d A^{+} t c d B^{+} c d t B^{-}$ & IR22 & $26^{\text {th }}$ November \\
\hline Hamburger after freezing & $\mathrm{D}$ & $t c d A^{+} t c d B^{+} c d t B^{-}$ & IR22 & $26^{\text {th }}$ November \\
\hline
\end{tabular}


whether this represents long-term persistence or (more likely) repeated contamination. Regardless, these results suggest that the hygiene procedures for cleaning and sanitation were not adequate. The standard operation procedure for sanitation used in processing plant $\mathrm{D}$ was washing the grinder with peracetic acid solution (4\%) then rinsing with warm potable water. In the other plants where no $C$. difficile was found, the procedure was washing with sodium hydroxide solution (5\%) followed by peracetic acid (4\%) washing. The usage of oxidative agents and acids such as hypochlorite, hydrogen peroxide and peracetic acid is recommended to break the chemical bonds of food soils that build up the biofilm [35]. It has also pointed out that any residual organic material involved in biofilm formation could facilitate the attachment of spores and vegetative cells to meat processed in a grinder [11].

Of 28 hamburger samples taken at each step after molding and freezing, 4 (7.1\%) were positive for $C$. difficile. As all positive isolates of $C$. difficile found in the same meat processing plant (D) belonged to an identical clone (RT 22), which was found on two separate occasions. This could suggest a common source of contamination, although inadequate data are available about strains found in food animals in Iran to properly interpret this finding. If this is a predominant food animal strain, the strain distribution noted here could simply reflect the background contamination of incoming meat products, although that would not explain the discrepancies in prevalence between facilities. Therefore, there must be concern that detection of the identical genotype (RT 22) from raw meat and final product at the same processing plant may indicate the persistence of this genotype during processing. In addition, colonization of the identical genotype in this processing plant may indicate the ineffectiveness of cleaning and sanitation. Complementary typing method such as multilocus variablenumber tandem-repeat analysis (MLVA) or PFGE are needed to further investigate the persistence of $C$. difficile in the environment [36].

Detection of $C$. difficile from hamburger patties in $2 / 28$ $(7.1 \%$; $95 \% \mathrm{CI}[0,23])$ after $24 \mathrm{~h}$ freezing at $-20^{\circ} \mathrm{C}$ indicates the survival of spores at freezing temperature, something that is well established in human fecal samples [14]. However there are no data on effect of freezing on survival of spores in meat.

The results of molecular characterizing of the 9 C. difficile strains are presented in Table 2. All isolates contained $t c d \mathrm{~B}$ while 7 isolates from 2 strains also possessed $t c d \mathrm{~A}$. Interestingly, all isolates lacked $c d t B$. This was unexpected given the high prevalence of binary toxin positive strains reported in other studies of raw meat, the predominance of ribotype 078 (a $c d t$ possessing strain) in food animals in various countries and the commonness of $c d t B$ in human isolates from a recent study $[6,9,13]$. These results indicate that further study of the strain distribution of $C$. difficile in animals and humans in the region is required.

PCR ribotyping of 9 isolates categorized into four ribotypes (IR 21, IR22, IR23 and IR24) (Table 2). Ribotype IR 22 was the most frequently $6 / 9(66.6 \%)$ encountered in our study. This genotype isolated from raw meat, environmental samples and hamburger both after forming and freezing in one processing plant (D), suggests that raw meat may be the major source of contamination. However the specific source of $C$. difficile in meat needs to be established. The gastrointestinal tract is the most important source of $C$. difficile contamination [9].Transmission through animals' hides, the slaughterhouse environment, the processing facility environment, processing equipment and the hands of personnel handling meat, must also be considered [9].

Inactivation of $C$. difficile spores by most of the cleaning and sanitation practices is difficult; therefore its accumulation in the environment increases the possibilities for contamination of meat. Ribotype IR 22 was isolated from various stages in processing plant $D$ in both visits in the summer and autumn suggesting the excellent survival of spores in the processing plant. Ribotypes IR23 and IR24 were also found in processing plant $\mathrm{D}$ suggesting a relatively higher genetic diversity among $C$. difficile in this processing plant. Ribotype IR21 was the only distinct genotype found in beef meat imported from Brazil indicating the possibility of a geographical relationship of the genotypes.

Recently, hyper-virulent PCR ribotype 027 has emerged in North America and Europe in links to the hospital outbreaks [2]. This strain has not been reported yet in Iran in either food or clinical samples $[9,17]$, potentially due to the lack of sufficient research in this area. Ribotype 027 also was not found in the present study, nor was ribotype 078 , based on inference of the lack of $c d t B$ in any isolate. We have previously reported ribotype 078 as a common strain in both humans and meat in Iran $[9,17]$, so the absence of this strain in the current study was surprising.

This study is subjected to some limitations. First, sampling were conduced based on expiry date of ingredients where non-meat products kept for a significantly longer times. Therefore these products sampled less frequently than meat, resulting unbalanced sampling. Second limitation of this study is that only ribotyping used as strains characterization. Complementary typing methods such as MLVA or ideally whole genome sequencing would be needed to further investigate the epidemiology of $C$. difficile in the hamburger production facilities. Third, the possibility of lab cross-contamination of samples cannot be dismissed, although it may be unlikely for reasons cited above.

\section{Conclusions}

In conclusion, the study demonstrated the existence of toxigenic $C$. difficile in hamburger processing plants 
through different potential reservoirs such as raw meat and facilities. Occurrence of $C$. difficile in hamburger as a commonly consumed food in Iran is of public health significance although hyper-virulent strains of ribotype 027 and 078 were not found in this study. For reduction or prevention of $C$. difficile prevalence in food products, Good Manufacturing practices (GMP) and Hazard Analysis Critical Control Point (HACCP) system should be applied in food industries and followed by post-production control procedures by consumers such as proper cooking based on the adequate time for destruction of $\mathrm{C}$. difficile spores [37]. Susceptible individuals with increased risk for development of CA-CDI should be also educated to minimize the exposure to this pathogen in the food supply [37].

\section{Abbreviations \\ C. difficile: Clostridium difficile; CDI: C. difficile infection; CA-CDI: Community associated- $C$. difficile infection; PCR: Polymerase chain reaction.}

\section{Competing interests}

The authors declare that they have no competing interests.

\section{Authors' contributions}

The project was performed by ZE, JSW, HE, MJ and MCh. DNA extraction, PCR techniques were performed by ZE and MJ. Sample collection, culture, statistical analysis and manuscript writing were performed by ZE, JSW and MJ. All authors read and approved the final manuscript.

\section{Acknowledgements}

We thank Akbar Ansarian in Deputy of Food and Drug in Isfahan University of Medical Sciences for assistance of sample gathering, Parisa Shoaei for the full cooperation in practical sections of plan and Mohammad Reza Marasi for statistical analysis.

\section{Author details}

${ }^{1}$ Department of Food Science and Technology, Science and Research Branch, Islamic Azad University, Tehran, Iran. ${ }^{2}$ Department of Pathobiology and Centre for Public Health and Zoonoses, Ontario Veterinary College, University of Guelph, Guelph, Ont N1G2W1, Canada. ${ }^{3}$ Department of Animal Science, Faculty of Agriculture and Natural Resources, Tehran Science and Research Branch, Islamic Azad University, Tehran, Iran.

Received: 7 April 2014 Accepted: 4 November 2014 Published online: 25 November 2014

\section{References}

1. Martin H, Willey B, Low DE, Staempfli HR, McGeer A, Boerlin P, Mulvey M, Weese JS: Characterization of Clostridium difficile strains isolated from patients in Ontario, Canada, from 2004-2006. J Clin Microbiol 2008, 46:2999-3004

2. Warny M, Pepin J, Fang A, Killgore G, Thompson A, Brazier J, Frost E, McDonald LC: Toxin Production by an emerging strain of Clostridium difficile associated with outbreaks of severe disease in North America and Europe. Lancet 2005, 366:1079-1084.

3. Rodriguez-Palacios A, Staempfli HR, Duffield T, Weese JS: Clostridium difficile in retail ground meat, Canada. Emerg Infect Dis 2007, 13:485-487.

4. Songer JG, Trinh HT, Killgore GE, Thompson AD, MCDonald LC, Limbago BM: Clostridium difficile in retail meat products, USA, 2007. Emerg Infect Dis 2009, 15:819-821.

5. Weese JS, Avery BP, Rousseau J, Reid-Smith RJ: Detection and enumeration of Clostridium difficile spores in retail beef and pork. Appl Environ Microbiol 2009, 75:5009-5011.

6. Curry SR, Marsh JW, Schlackman JL, Harrison LH: Prevalence of Clostridium difficile in uncooked ground meat products from Pittsburgh,

Pennsylvania. Appl Environ Microbiol 2012, 78:4183-4186.
7. Susick EK, Putman M, Bermudez M, Thakur S: Longitudinal study comparing the dynamics of Clostridium difficile in conventional and antimicrobial free pigs at the farm and slaughter. Vet Microbio/ 2012 157:172-178.

8. Quesada-Gomez C, Mulvey MR, Vargas P, Gamboa-Coronado MDM, Rodriguez C, Rodriguez-Cavillini E: Isolation of toxigenic and clinical genotype of Clostridium difficile in retail meats in Costa Rica. J Food Prot 2013, 76:348-351.

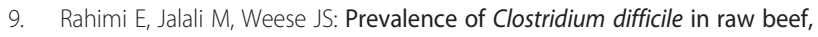
cow, sheep, goat, camel and buffalo meat in Iran. BMC Public Health 2014, 14:119. doi:10.1186/1471-2458-14-119.

10. Jhung MA, Thompson AD, Killgore GE, Zukowski WE, Songer G, Warny M, Johson S, Gerding DN, McDonald LC, Limbago BM: Toxinotype V Clostridium difficile in humans and food animals. Emerg Infect Dis 2008, 14:1039-1045

11. Houser BA, Soehnlen MK, Wolfgang DR, Lysczek HR, Burns CM, Jayarao BM: Prevalence of Clostridium difficile toxin genes in the feces of veal calves and incidence of ground veal contamination. Foodborne Pathog Dis 2012, 9:32-36

12. Harvey RB, Norman KN, Andrews K, Nory B, Hume ME, Scanlan CM, Hardin MD, Scott HM: Clostridium difficile in retail meat and processing plants in Texas. J Vet Diagn Invest 2011, 23:807-811.

13. Hawken $P$, Weese JS, Friendship $R$, Warriner $K$ : Carriage and dissemination of Clostridium difficile and methicillin resistant staphylococcus aureus in pork processing. Food Control 2013, 31:433-437.

14. Freeman J, Wilcox MH: The effects of storage conditions on viability of Clostridium difficile vegetative cells and spores and toxin activity in human faeces. J Clin Pathol 2003, 56:126-128.

15. Rodriguez-Palacios A, Reid-Smith RJ, Staempfli HR, Weese JS: Clostridium difficile survives minimal tempertature recommended for cooking ground meats. Anaerobe 2010, 16:540-542.

16. Rodriguez-Palacios A, LeJeune JT: Moist-heat resistance, spore aging, and uperdormancy in Clostridium difficile. Appl Environ Microbiol 2011, 77:3085-3091.

17. Jalali M, Khorvash F, Warriner K, Weese JS: Clostridium difficile infection in an Iranian hospital. BMC Res Notes 2012, 5:159. doi:10.1186/1756-0500-5-159.

18. Lemee $\mathrm{L}$, Dhalluin A, Testelin S, Mattrat M, Maillard K, Lemeland J, Pons JL: Multiplex PCR targeting tpi (triose phosphate isomerase), tcdA (toxin A), and $\mathrm{tcdB}$ (toxin $\mathrm{B}$ ) genes for toxigenic culture of Clostridium difficile. J Clin Microbiol 2004, 42:5710-5714.

19. Stubbs S, Rupnik M, Gibert M, Brazier J, Duerden B, Popoff M: Production of actin-specific ADP-ribosyltransferase (binary toxin) by strains of Clostridium difficile. FEMS Microbiol Lett 2000, 186:307-312.

20. Bidet P, Barbut F, Lalande V, Burghoffer B, Petit J: Development a new PCRribotyping method for Clostridium difficile based on ribosomal RNA gene sequencing. FEMS Microbiol Lett 1999, 175:261-266.

21. Bakri MM, Brown DJ, Butcher JP, Sutherland AD: Clostridium difficile in ready-to-eat salads, Scotland. Emerg Infect Dis 2009, 15:817-818.

22. Metcalf DS, Costa MC, Dew WMV, Weese JS: Clostridium difficile in vegetables, Canada. Lett Appl Microbiol 2010, 51:600-602.

23. Pasquale V, Romano VJ, Rupnik M, Dumontet S, Ciznar I, Aliberti F, Mauri F, Saggiomo V, Krovasec K: Isolation and characterization of Clostridium difficile from shellfish and marine environments. Folia microbiologica 2011, 56:431-437.

24. Metcalf D, Avery BP, Janecko N, Matic N, Reid-Smith R, Weese JS: Clostridium difficile in seafood and fish. Anaerobe 2011, 17:85-86.

25. Pasquale V, Romano V, Rupnik M, Capuano F, Bove D, Aliberti F, Krovacek K, Dumontet S: Occurrence of toxigenic Clostridium difficile in edible bivalve molluscs. Food microbial 2012, 31:309-312.

26. Zidaric V, Rupnik M: Clostridium difficile in meat products, eggs and vegetables in Slovenia. The 4th International Clostridium difficile Symposium, European Society of Clincial Microbiology and Infectious Diseases (ESCMID). Poster no. 118. 2012

27. Von Abercron SMM, Karlsson F, Wigh GT, Wierup M, Krovacek K: Low occurrence of Clostridium difficile in retail ground meat in Sweden. J Food Prot 2009, 72:1732-1734.

28. Rodriguez-Palacios A, Reid-Smith RJ, Staempfli HR, Daignault D, Janecko N, Avery BP, Martin H, Thompson AD, McDonald LC, Limbago B, Weese JS: Possible seasonality of Clostridium difficile in retail meat, Canada. Emerg Infect Dis 2010, 15:802-805.

29. Esfandiari Z, Jalali M, Ezzatpanah H, Weese JS, Chamani M: Prevalence and characterization of Clostridium difficile in beef and mutton meats of Isfahan region. Iran. Jundishapur J Microbiol 2014, 7:e16771. 
30. de Boer E, Zwartkruis-Nahuis A, Heuvelink AE, Harmanus C, Kuijper EJ: Prevalence of Clostridium difficile in retailed meat in the Netherlands. Int J Food Microbiol 2011, 144:561-564.

31. Guy R: Extrusion Cooking. Technologies and Applications. England: Woodhead Publishing Group Limited, CRC press, Cambridge; 2001:21.

32. Rahman MS: Handbook of Food Preservation. New York: Taylor \& Francis Group, CRC Press; 2007:769.

33. Lara JD, Fernandez PS, Periago MP, Palop A: Irradiation of spores of Bacillus cereus and Bacillus subtilis with electron beeam. Innovat Food SCI Emerg Technol 2002, 3:379-384.

34. Al Saif N, Brazier JS: The distribution of Clostridium difficile in the environment of South Wales. J Med Microbiol 1996, 45:133-137.

35. Cramer MC.Food Plant Sanitation: Design, Maintenance and Good Manufacturing Practices. New York: Taylor \& Francis Group, CRC Press; 2006:19.

36. Wei HL, Kao CW, Wei SH, Tzen JTC, Chiou CS: Comparison of PCR ribotyping and multilocus variable-number tandem-repeat analysis (MLVA) for improved detection of Clostridium difficile. BMC Microbiol 2011, 11:217.

37. Rodriguez-Palacios A, Borgmann S, Kline TR, Lejeune JT: Clostridium difficile in foods and animals: history and measures to reduce exposure. Anim Health Res Rev 2013, 14:11-29.

doi:10.1186/s12866-014-0283-6

Cite this article as: Esfandiari et al:: Occurrence of Clostridium difficile in seasoned hamburgers and seven processing plants in Iran. BMC Microbiology 2014 14:283.

\section{Submit your next manuscript to BioMed Central and take full advantage of:}

- Convenient online submission

- Thorough peer review

- No space constraints or color figure charges

- Immediate publication on acceptance

- Inclusion in PubMed, CAS, Scopus and Google Scholar

- Research which is freely available for redistribution 